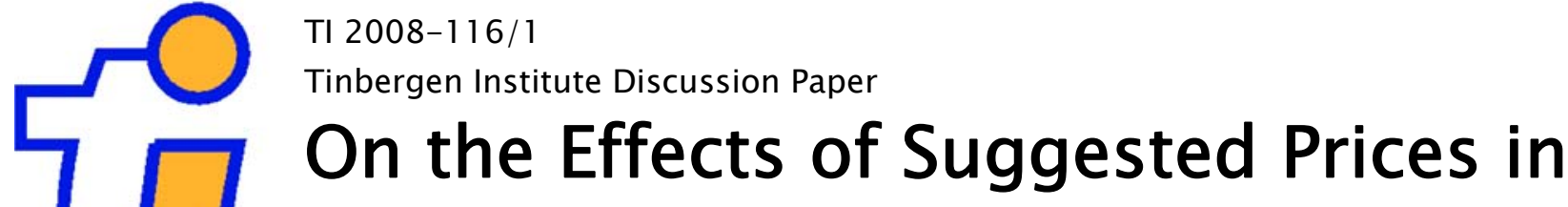 Gasoline Markets
}

Riemer P. Faber

Maarten C.W. Janssen 1,2

' Department of Economics, Erasmus School of Economics, Erasmus University Rotterdam, and Tinbergen Institute;

2 Department of Economics, University of Vienna. 


\section{Tinbergen Institute}

The Tinbergen Institute is the institute for economic research of the Erasmus Universiteit Rotterdam, Universiteit van Amsterdam, and Vrije Universiteit Amsterdam.

Tinbergen Institute Amsterdam

Roetersstraat 31

1018 WB Amsterdam

The Netherlands

Tel.: +31(0)205513500

Fax: $+31(0) 205513555$

Tinbergen Institute Rotterdam

Burg. Oudlaan 50

3062 PA Rotterdam

The Netherlands

Tel.: + $31(0) 104088900$

Fax: $+31(0) 104089031$

Most TI discussion papers can be downloaded at http://www.tinbergen.nl. 


\title{
ON THE EFFECTS OF SUGGESTED PRICES IN GASOLINE MARKETS ${ }^{1}$
}

\author{
Riemer P. Faber ${ }^{2}$ and Maarten C.W. Janssen ${ }^{3}$
}

This Version

November 17, 2008

\begin{abstract}
This article analyzes the role of suggested prices in the Dutch retail market for gasoline. Suggested prices are announced by large oil companies with the suggestion that retailers follow them. There are at least two competing rationales for the existence of suggested prices: they may either help retailers translate changes in international gasoline spot market prices into retail prices, or they may coordinate retail prices. We show that there is, next to the international spot market prices, additional information in suggested prices that explains retail prices. Therefore, we conclude that suggested prices help to coordinate retail prices.
\end{abstract}

Key Words: gasoline markets, collusion, price setting, suggested prices

\section{JEL code: L11, L42, L65}

\footnotetext{
${ }^{1}$ We thank Christiaan Heij and Dick van Dijk for very stimulating discussion and suggestions regarding methodology, and Gerhard Orosel, Emiel Maasland, Nick Vikander, Jan Kees Winters, Jarig van Sinderen and Ron Kemp and audiences at the European Economic Association meeting (Milan 2008), the Tinbergen Institute and the University of Vienna for helpful comments. We thank Rikkert Nachtegaal for help with the data.

${ }^{2}$ Department of Economics, Erasmus University Rotterdam and Tinbergen Institute. P.O. Box 1738, 3000 DR Rotterdam, The Netherlands. E-mail: faber@few.eur.nl

3 Department of Economics, University of Vienna, Erasmus University Rotterdam and Tinbergen Institute. Hohenstaufengasse 9, 1010 Vienna, Austria. E-mail: maarten.janssen@univie.ac.at
} 


\section{Introduction}

Both from an academic and from a more practical point of view, there is a lot of interest in what constitutes price setting under normal conditions of competition and where the boundary with price collusion lies. This issue is particularly prominent in connection with the issue of how to interpret the existence of suggested prices. We define suggested prices as prices that are announced with the suggestion that retailers follow them. Suggested prices can be chosen by professional organizations (e.g., the organization of notaries, or of psychologists) or by large producers higher up in the product chain (such as oil companies). Suggested prices can be communicated openly via websites or can be more hidden, via letters or e-mails sent only to retailers. Depending on the sector, suggested prices can be changed either infrequently or on a daily basis. Suggested prices are not binding in any legal way and retailers are free to deviate and charge higher or lower retail prices as they wish. As such, they should not be considered in the same way as minimum or maximum prices. Nevertheless, there is a wide suspicion that suggested prices distort the normal functioning of markets and act as an attraction or focal point for firms coordinating their pricing decisions.

Indeed, there are quite a few cases where different competition authorities have argued that by setting suggested prices, companies or professional organizations have violated competition law. Recently, one such a case was where the Dutch competition authority (NMa) decided that several Dutch organisations for psychology and psychiatry were guilty of violating competition law as they advised their members via their website how much to charge per hour given the costs members typically would encounter. ${ }^{1}$ What, according to the organization, was meant as an aid to their members, was judged by the Dutch competition authority as a way to coordinate pricing decisions of individual entrepreneurs above competitive levels. The Dutch competition authority argued that suggested prices helped to considerably reduce the uncertainty concerning competitors' price setting behaviour. Uncertainty concerning competitors' main strategic decisions was considered to be crucial to the competitive

\footnotetext{
${ }^{1}$ See NMa decision case 3309/NIP, LVE, NVP and NVVP 2004. The decision has been successfully challenged by the professional organizations involved. In a decision on October 6, 2008 the court of appeal $(\mathrm{CBb})$ cancelled the decision on the basis that it was not clear that price was a decisive factor in the decision process of the consumers while choosing a psychologist (LJN: BF8820, CBb, AWB 06/667).
} 
process. The decision of the Dutch competition authorities was based, among other things, on some EU decisions (e.g., concerning suggested prices in the crane renting sector) taken already as early as $1995 .^{2}$

A similar ruling was made in a private US case on petroleum products. ${ }^{3}$ The complaint was that oil companies conspired to raise or stabilize prices by disseminating information concerning wholesale and retail prices, with the purpose of quickly informing competitors in the hope they would follow suit. The court's analysis was to a large extent based on the judgment that they did not see any other business purpose than to facilitate interdependent or collusive interaction.

As far as gasoline markets are concerned, suggested prices are quite common in many European countries, such as the Netherlands, Germany ${ }^{4}$ and Italy $^{5}$ (see also OECD 2001). Typically, larger oil companies announce on a daily basis on their websites the prices they advise retailers to set for their gasoline. ${ }^{6}$ As the international gasoline prices change rapidly (from day to day), suggested prices also fluctuate frequently. Retailers are free to deviate from these prices. Apparently, as the existence of these suggested prices is not a secret, the competition authorities think these rules do not obstruct the competitive process in this particular market.

What can be the economic rationale for setting suggested prices in the gasoline retail market and what can be the rationale for allowing this practice in this sector, in spite of the fact that similar practices are not allowed in other sectors? We can think of two reasons why oil companies publish suggested prices: (i) to help small retailers by informing them how they could take the rapidly changing gasoline spot market price into account when setting retail prices, and (ii) to coordinate pricing decisions. We do

\footnotetext{
${ }^{2}$ See, e.g., XXVth Report on Competition Policy 1995, European Commission, p. 118.

${ }^{3}$ See, e.g., In re Coordinated Pretrial Proceedings in Petroleum Products Antitrust Legislation 906 F.2d 432 (1990) and Hay (1999). Another interesting case is Borenstein (2004).

${ }^{4}$ Formally, the Aral website in Germany does not mention suggested prices, but "Durchschnittspreise" (average prices). However, this listed price has a common effect in that this price is commonly observable and is changed every day at 08.00 hours.

${ }^{5}$ Recently oil companies in Italy decided not to publish suggested prices anymore after an investigation of the Italian competition authority (see Autorità Garante della Concorrenza e del Mercato, press release number 5/2007 (I681 - Retail fuel prices (start of investigation)) and press release number 92/2007 (Fuel: oil companies' commitments accepted)).

${ }^{6}$ See, e.g., www.bp.nl for the Netherlands and www.aral.de for Germany.
} 
not see other convincing business purposes. ${ }^{7}$ Some oil companies explicitly claim to have suggested prices for the first reason. ${ }^{8}$

It is important to realize that the first reason can also cause price coordination between retailers, namely with the change of the gasoline spot market price as focal point. However, this is not necessarily more harmful for consumers than the best alternative situation for gasoline stations if there would not be suggested prices. The gasoline spot market price, the cost of the major input for a liter of gasoline, is public information. If suggested prices would not exist, coordination on the change of the gasoline spot market price would still be possible for retailers. As a consequence, if suggested prices just contain changes in the spot market price (information that is already publicly available), then suggested prices do not provide additional coordination possibilities compared to the situation without suggested prices. Note that this is different in most other markets (such as the psychologists, mentioned before) where a clear alternative focal point does not exist. ${ }^{9}$ Thus, the above may be used as an argument for not prohibiting suggested prices in gasoline markets.

The main question this paper addresses is whether changes in suggested prices simply summarize in a convenient way changes in the common input price, or whether they have an additional coordinating effect on retail prices. ${ }^{10}$ An additional question we address is what the role of multiple suggested prices is. In the gasoline market, most of the larger oil companies set their own suggested price. We can therefore distinguish between a general, across brand, influence of suggested prices on retail prices and a brand-specific effect.

\footnotetext{
${ }^{7}$ In some other sectors where quality in presale service is important, a rationale for suggested prices may be to try to prevent firms to free ride on other firm's service provision. This reason does not seem to be important in the gasoline sector, however, as pre-sale service does not seem to be important due to the fact that gasoline is a perfectly homogeneous good.

${ }^{8}$ See, e.g., www.shell.nl and Shell (2001).

${ }^{9}$ Another difference with many other markets is that in the gasoline sector input prices change rapidly.

${ }^{10}$ Another paper that quantifies the impact of focal points on price coordination is Knittel and Stango (2003). This paper studies government imposed nonbinding price ceilings in the American credit card market. Other papers on the Dutch gasoline market are Bettendorf, Van der Geest and Varkevisser (2003) and Bettendorf, Van der Geest and Kuper (2008). These papers study asymmetric pricing and use spot market prices and suggested prices, not actual retail prices. Foros and Steen (2008) study Norwegian gasoline prices and find weekly price cycles. They argue that the suggested price and retail price are related on the first day of a cycle.
} 
To analyze these questions, we use panel data techniques on a Dutch dataset consisting of daily gasoline prices of (almost) all gas stations over the period May 30 2006 - July 202008 and daily suggested prices of the five largest oil companies. We find that retail prices can be explained by information in suggested prices that is not contained in the international spot market price. Our main conclusion is that suggested prices have a coordinating effect on retail prices, both across brands and within brands.

The rest of the paper is organized as follows. Section 2 describes the gasoline market in the Netherlands, the different type of gasoline stations that exist and the way suggested prices are communicated. Section 3 provides details on the dataset and some descriptive statistics. Section 4 discusses the equations we estimate and Section 5 presents the main results. Section 6 provides some additional analysis falsifying an alternative hypothesis that might explain our findings. Section 7 concludes and provides a discussion.

\section{The Dutch gasoline market ${ }^{11}$}

There are around 4300 gasoline stations in the Netherlands with the five largest companies (BP, Esso, Shell, Total and Texaco) having a total market share of around $70 \%$ (measured as the total number of stations using the "flag" of these five companies divided by the total number of stations). Roughly speaking there are three types of ownership models: some stations (including almost all the larger stations along the highways) are company-owned and company-operated (coco), other stations are company-owned and dealer-operated (codo) and the remaining stations are dealerowned and dealer-operated (dodo). Coco stations are not free to set their own gasoline prices: these prices are set at the central company level. The dealers of a codo station rent the stations from the oil company, participate in the company's sales and loyalty programs, but are free to set their own prices. Finally, dodo stations operate most independently from the larger oil companies, although even these stations have to buy the gasoline they sell from the oil company. Approximately $60 \%$ of the stations are

\footnotetext{
${ }^{11}$ If not noted otherwise, most data given in this section are based on BOVAG (2006).
} 
dealer-owned. We do not know exactly how many stations are dealer-operated, but rough estimates indicate that this percentage is $80 \%$.

Gasoline prices in the Netherlands are among the highest in Europe. One may quote several reasons for these high gasoline prices at the gas station. First, excise duty and VAT account for approximately $60 \%$ of the retail price of a liter Euro95 and are in absolute terms among the highest taxes in Europe. Second, the Netherlands has a very dense network of highways and accordingly a relatively high percentage of the total number of gas stations being located along the highway (more than 5\% compared to a number slightly above 1\% in France and the UK). It is known that highway users are less price sensitive than other users. Finally, almost no supermarket chain has the permission to sell gasoline in the Netherlands. ${ }^{12}$ In countries such as France, and to a smaller extent the UK, supermarkets tend to play the role of price fighters encouraging price competition on a wider scale.

Euro95 and Diesel are the most important gasoline products in the Netherlands. Of all gasoline product liters sold, roughly $38 \%$ is Euro95 and 54\% is Diesel. Euro95 is most commonly used in the Netherlands by private users and Diesel is most commonly used for leased cars and trucks. The total volume of sales seems to have stabilized in recent years with total kilometers still rising slightly, ${ }^{13}$ but this effect is compensated by the use of more energy efficient vehicles. The use of LPG has declined over the years.

The larger oil companies have suggested prices that they determine on a daily basis. Oil companies differ in the way they make their suggested prices public. Some publish their suggested prices on their webpage (BP, Total and many smaller oil companies), others do not publish suggested prices (Esso, Shell and Texaco). ${ }^{14}$ Nevertheless, all these suggested prices are publicly available since they are published

\footnotetext{
${ }^{12} 0.9 \%$ of all gasoline volume sold in the Netherlands is sold via a supermarket, whereas this number is $54 \%$ and $29 \%$ for France and the UK, respectively.

${ }^{13}$ Because of the traffic density, cars cannot be used much more frequently it seems.

${ }^{14}$ Shell published suggested prices on its website until March 152006.
} 
every day on the websites of the ANWB (the Dutch automobile club with almost 4 million members) and United Consumers. ${ }^{15}$

The suggested prices of different oil companies do not seem to be very different from one another. In practice, the suggested price acts as a reference price. Dealer-operated stations decide whether or not to give a "discount" compared to this daily price. Stations along the highway usually follow the suggested prices exactly, whereas nonhighway stations give discounts more frequently. Gasoline stations advertise this discount explicitly (and often not the real price) as a price discount with reference to the suggested price (whatever the level of that price may be).

Shell (the largest oil company) has explicitly claimed in the past that they use their suggested price as a way to make gasoline spot market price changes transparent to their dealers. They also published detailed descriptions on how they calculate their suggested prices (See, e.g., Shell Venster (2001) and the Shell website). They claim that every morning they take the spot market price of the previous day (which is the most recent price available) and add different taxes and margins (for transport, sales costs, etc.) to come up with a price they think gasoline stations should charge for their gasoline. If this price is different from the current price, a pricing committee meets to determine whether they change the suggested price and by how much. If the price change is decided, the new price (which is valid from the next day onwards) is communicated via fax and e-mail to all dealers in the evening. Dealers can then update their prices the next morning. If this decision process is indeed followed, the delay between changes in gasoline spot market prices and prices at the stations is exactly two days.

The input prices for gasoline are closely related to the international market for the respective inputs. Although the large oil companies are fully integrated from extracting oil to selling gasoline, the Dutch gasoline sales divisions mainly buy their gasoline on the Amsterdam-Rotterdam-Antwerp (ARA) spot market which supplies

\footnotetext{
${ }^{15}$ This latter site also links the prices to other websites like the website of a car magazine and www.nu.nl, a Dutch news website (the tenth most visited website in the Netherlands). See www.anwb.nl and www.unitedconsumers.com.
} 
large parts of western Europe. Shell claims that even if the Dutch sales division buys gasoline from a production division, this spot market price is used as internal price. ${ }^{16}$

\section{Data and first analysis}

Dutch retail gasoline prices are published daily on the webpage of Athlon Car Lease. ${ }^{17}$ This company leases cars to other firms including a so-called "fuel card". If the driver of the car tanks gasoline, he shows the card to the gas station and the retailer electronically sends the bill with price and quantity information to the lease company at the same moment in time. As a result, Athlon Car Lease obtains gasoline price notations from 120,000 drivers, who fill up on average twice a week, from all over the Netherlands. Athlon Car Lease puts the data on gasoline prices on its website and we have downloaded the data daily over the period May 302006 - July 202008 . As indicated in the previous section, there are approximately 4300 gasoline stations in the Netherlands, of which over 3600 are included in this dataset. Stations that are not included in the dataset seem to be mostly minor and non-active stations randomly distributed over the country. Data are available for seven different kinds of gasoline: Euro95, Diesel, Super, Super Plus, Special Euro95, Special Diesel and untaxed Diesel. Since the normal versions of Euro95 and Diesel are most commonly used, we focus our analysis on these two types. Per day we have in total approximately 6,000 unique station-gasoline type-price quotations. ${ }^{18}$ Note that we have for each stationgasoline type combination a maximum of one price quotation per day. Since less busy stations have a lower probability of being visited by a driver of a car leased from Athlon Car Lease, the dataset contains more quotations of more busy stations. This does not have an impact on our analysis, however, as there is no indication that the pricing decisions of larger gasoline stations differs significantly from that of smaller ones (after correction for ownership structure). It is also of importance to note that drivers do not have to pay themselves for the gasoline (as the firm that employs the driver does). So more expensive stations are not avoided by these users. Casual observation shows that cheaper stations are not avoided either.

\footnotetext{
${ }^{16}$ www.shell.nl

${ }^{17}$ www.athloncarlease.nl

${ }^{18}$ Over the whole dataset, only a couple of observations are suspicious. These seem to be cases where a certain type of gasoline is reported as another kind of gasoline. We have deleted these quotations.
} 
We matched individual stations in the dataset to lists of individual characteristics of gasoline stations, namely owner and brand of a station and whether a station is located along a highway. ${ }^{19}{ }^{20}$ We do not have data on the operator of a station, but we do know the ownership structure. This means we are able to filter out the stations where an oil company decides on the price.

We downloaded the suggested prices from the United Consumers website during the sample period. This website contains daily suggested prices of the five largest oil companies for eleven different types of gasoline (some types are brand specific). The spot market notation we use is the daily Platt's Barges FOB Rotterdam High (series: Premium Gasoline 10 PPM for Euro95 and Diesel 10 PPM for Diesel). Shell uses the same notation for calculating the suggested price (Shell 2001).

The dollar-euro exchange rate and data on taxes are obtained via the websites of respectively the European Central Bank and the Dutch Ministry of Finance. We converted all prices in price per liter (excluding taxes) in euros.

\section{A first look at the data}

Figure 1 shows the development over time of the two-day lagged spot market price, the retail price of a representative Shell station and the Shell suggested price for one liter Euro95 during the sample period. Figure A1 in Appendix A shows the same data for Diesel.

For illustration purposes, we plot some figures with Euro95 prices over the last 100 days of the sample. Figure 2 shows the difference between the retail price and the Shell suggested price for four selected dealer-owned Shell gasoline stations. Figure 3 shows the difference between the retail price of the same four gasoline stations and the two-day lagged spot market price. Taken together, Figures 2 and 3 show that the difference between the suggested price and the retail price is more stable than the

\footnotetext{
${ }^{19}$ We obtained lists with the ownership structure and brand of a station from Catalist (a company collecting data on gasoline stations) and a list with highway stations from the Dutch Ministry of Finance.

${ }^{20}$ It may be that stations change their brand or ownership structure during the sample period. As we do not have information on this, we assume that stations do not change their brand and ownership structure.
} 
difference between the retail price and the spot market price. This suggests that these four gasoline stations set their prices using information from the Shell suggested price that is not contained in the spot market during the last 100 days of the sample.

We are also interested in whether suggested prices have a coordinating effect across different brands. This occurs if the correlation between suggested prices of different oil companies is stronger than the correlation of each one of them with the two-day lagged spot market price (and retailers follow suggested prices). Figure A2 in Appendix A shows the difference between the suggested price and spot market price of all five oil companies. The figure shows that oil companies often put the same additional information in their suggested prices on the same day. Over the whole sample, the suggested price of at least four (or all five) oil companies differs in exactly the same way from the two-day lagged spot market price at 61 (32) percent of the days. So it seems that there is a strong common component in the suggested prices. This explains why suggested prices may have a coordinating effect across brands.

Figure 1. Shell suggested price, retail price of a representative Shell station and spot market price for one liter Euro95

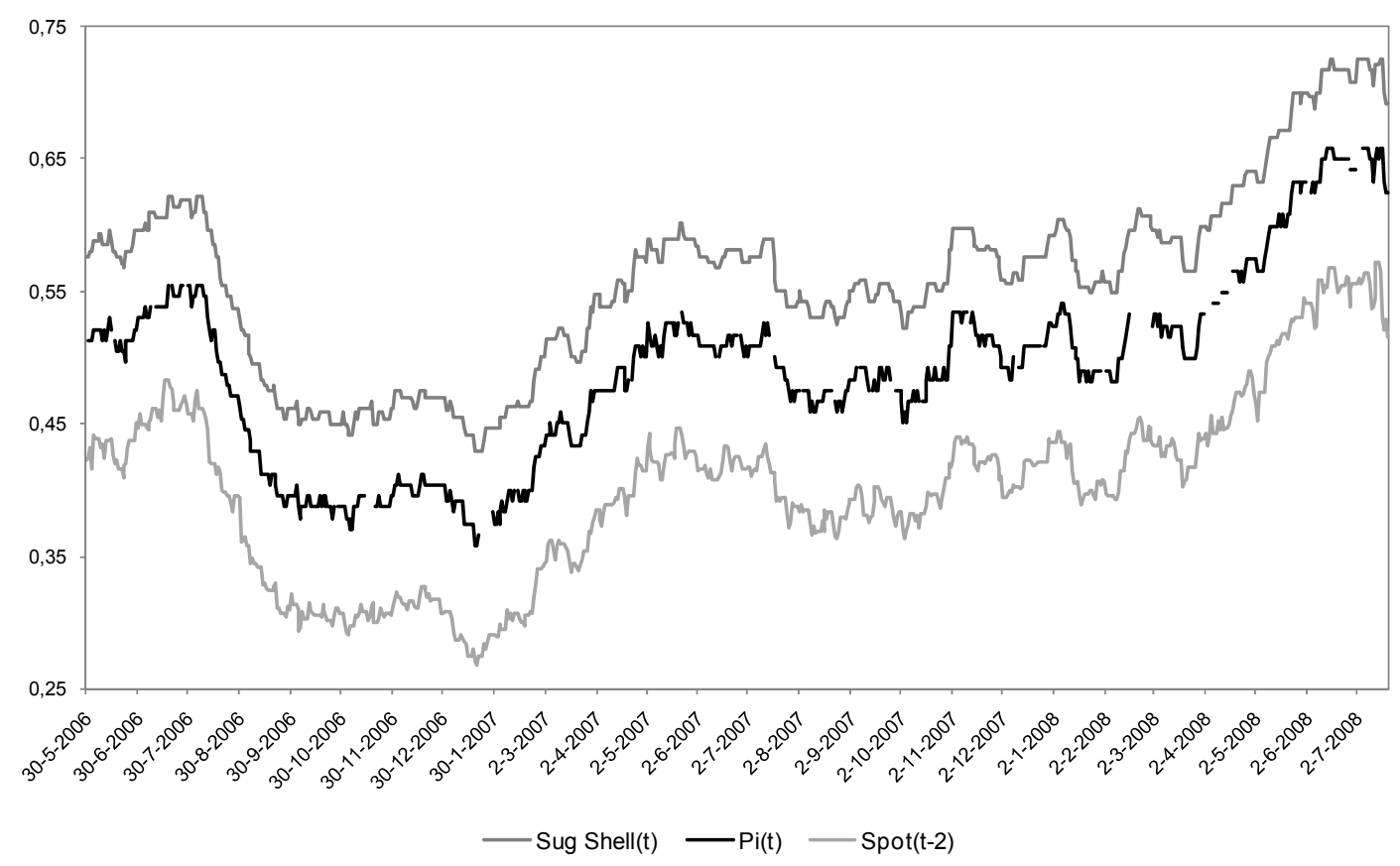

Notes: $\mathrm{T}=783$, price in euro per liter (excluding excise duty and VAT) 
Figure 4 shows the difference between the retail price of the four selected Shell gasoline stations and the average of the suggested prices of the other four oil companies. Figure 3 and 4 show that the difference between the retail price and the average suggested price is more stable than the difference between the retail price and the spot market price. This suggests that there is an across brand coordinating effect. In combination with Figure 2, Figure 4 shows that the difference between the retail price and the Shell suggested price is more stable than the difference between the retail price and the average suggested price. Thus, the Shell suggested price explains the retail price of the selected Shell stations better, suggesting that there is also a within brand coordinating effect. We will study these observations in a more structured way in Section 4 and 5.

\section{Methodology}

Before specifying the equations to be estimated, we test for the presence of unit roots and cointegration. Augmented Dickey-Fuller unit root tests indicate that the two-day lagged spot market price of both Euro95 and Diesel are integrated of order one. Two other variables that we will use in our equations are the difference between the suggested price and the two-day lagged spot market price (for all five brands and the average of the five suggested prices) and the difference between the suggested price of a brand and the average of the suggested prices of the other brands. Augmented Dickey-Fuller unit root tests on the individual series indicate that these two variables are stationary for all brands and for both Euro95 and Diesel. Augmented DickeyFuller Fisher panel unit root tests (Maddala and $\mathrm{Wu}$ 1999, Choi 2001) indicate that both Euro95 and Diesel retail prices are integrated of order one. Augmented DickeyFuller tests on individual price series of gas stations indicate that 98 percent of both Euro95 and Diesel price series are integrated of order one. We treat all the Euro95 and Diesel price series as integrated of order one. The panel cointegration test of Kao (1999) reveals homogeneous cointegration between retail prices and the two day lagged spot market price for Euro95 as well as for Diesel. 
Figure 2. Retail price - Shell suggested price (Euro95, for four Shell stations)

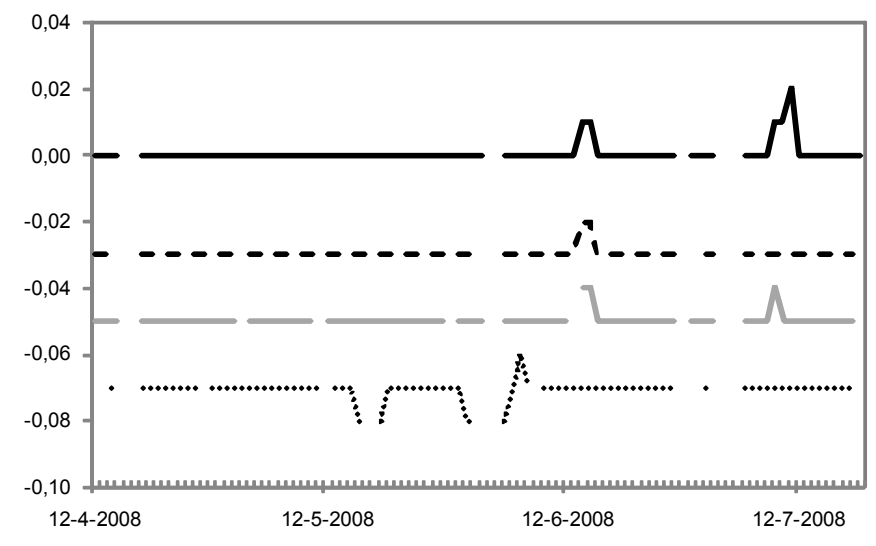

Figure 3. Retail price - Spot market price (Euro95, for four Shell stations)

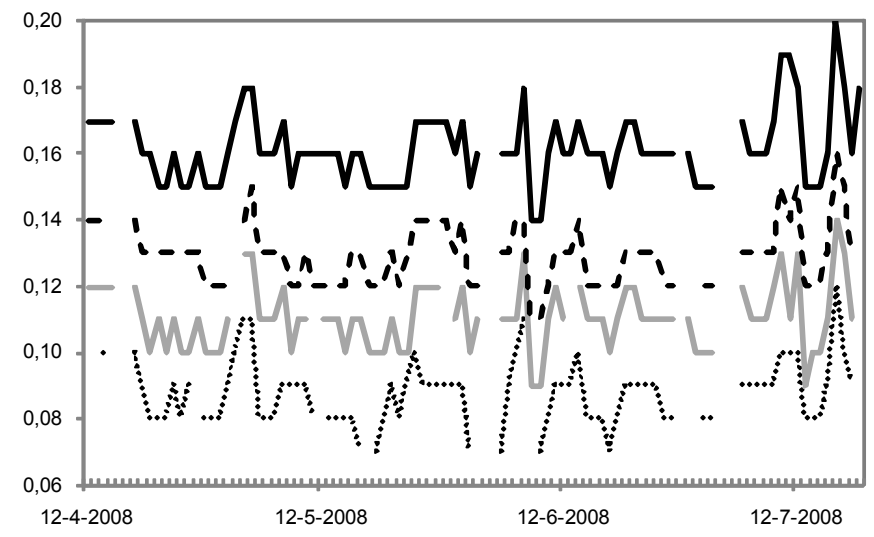

Figure 4. Retail price - Average of suggested prices of the four other brands (Euro95, for four Shell stations)

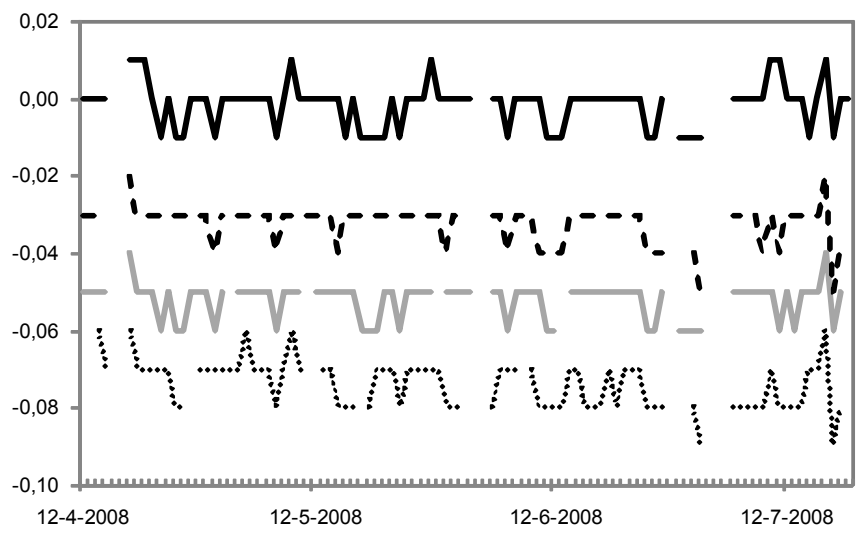


As explained in the introduction, our purpose is to study whether there is, next to the spot market price, additional information in suggested prices that gasoline stations use for setting their price. First, we study the general question whether suggested prices have a coordinating effect on retail prices of stations with different brands. This occurs if retailers use common elements which are next to the spot market price introduced by oil companies in their suggested prices. The most direct way to test the across brand coordination hypothesis is to model the gasoline retail price as follows:

$$
P_{i, t}=\widetilde{\beta} \operatorname{Spot}_{t-2}+\widetilde{\gamma}\left(\overline{\operatorname{Sug}}_{-i, t}-\operatorname{Spot}_{t-2}\right)+\widetilde{\eta}_{i}+\widetilde{\varepsilon}_{i, t}
$$

where: $P_{i, t}$ is the retail price of one liter of gasoline at station $i$ at day $t, \operatorname{Spot}_{t-2}$ is the gasoline spot market price at day $t-2$ and $\overline{S u g}_{-i, t}$ denotes the common component of the suggested prices and is the average of the suggested prices of all oil companies other than the oil company of the brand of station $i$ at day $t$. All three variables are measured in euro per liter and are excluding excise duty and VAT. Finally, $\tilde{\eta}_{i}$ is a station specific effect. ${ }^{21}$ As mentioned before in Section 2, we delay the spot market price of gasoline with two days, since this is the relevant input price for the suggested price. $^{22}$ The term in brackets on the right hand side of equation (1) captures the possible extra information contained in the average suggested price over and above the spot market price. If $\tilde{\gamma}$ is positive and significant, gasoline stations use this information for setting their prices.

However, the variables $P_{i, t}$ and $S_{p o t}$ in equation (1) are non-stationary. We therefore do not estimate equation (1) directly, but instead rewrite the equation into an Error Correction Model (ECM) with dynamics to take into account the cointegration of these two series. The ECM version of equation (1) is given by:

\footnotetext{
${ }^{21}$ We choose a linear relationship instead of a log specification because the data show that the absolute difference between the retail price and spot market price is stable and independent of the level of the spot market price (see also Borenstein, Cameron and Gilbert 1997).

${ }^{22}$ The spot market price has the highest correlation with the suggested price if we use a two-day lag.
} 


$$
\begin{aligned}
\Delta P_{i, t}= & \sum_{k=1}^{q-1} \alpha_{k} \Delta P_{i, t-k}+\sum_{k=0}^{r-1} \beta_{k} \Delta \operatorname{Spot}_{t-2-k}+\sum_{k=0}^{w-1} \gamma_{k} \Delta\left(\overline{\operatorname{Sug}}_{-i, t-k}-\operatorname{Spot}_{t-2-k}\right)+ \\
& \phi\left[P_{i, t-1}-\beta^{*} \operatorname{Spot}_{t-3}-\gamma^{*}\left(\overline{\operatorname{Sug}}_{-i, t-1}-\operatorname{Spot}_{t-3}\right)-\eta_{i}^{*}\right]+\varepsilon_{i, t}
\end{aligned}
$$

where $\Delta$ denotes the first-difference operator and $\varepsilon_{i t}$ is allowed to be heteroskedastic (both across stations and time), serially correlated and cross-sectionally correlated (contemporaneous and lagged). ${ }^{23}$ Due to the strict order in which the retail prices and the suggested price are determined (i.e., retail prices follow the suggested prices and not vice versa) endogeneity issues between retail prices and suggested prices are not important, i.e., the suggested price really is exogenous with respect to the retail price.

The ECM shows how deviations of the gasoline retail price from a long-term equilibrium price relation are corrected. In equation (2) the change in the gasoline retail price depends on the previous change of the gasoline retail price, the current (and previous) change in the spot market price and the current (and previous) change in the difference between the average suggested price and the spot market price, plus the error correction term. This last term is the part between the square brackets and defines the long-run or "equilibrium" relationship between the variables involved. This relationship basically is a version of equation (1). The speed of adjustment toward equilibrium is measured by the parameter $\phi$ (where a value of $\phi$ of -0.5 means that if the retail price on day $t-1$ is one cent larger than the equilibrium retail price, the retail price on day $t$ will decrease by half a cent). The parameters $\beta$ estimate the impact of the spot market price on the gasoline retail price and the $\gamma$ 's estimate the impact of the possible additional information in the general component of the suggested prices. If the suggested price does not have an additional explanatory effect, then the $\gamma$ 's should equal 0 .

As mentioned in the introduction and in Section 2, the gasoline sector is special in that different brands publish their own suggested price. It is therefore of additional interest to study if brand specific suggested prices have an additional coordinating effect on

\footnotetext{
${ }^{23}$ Contemporaneous correlation might for example exist because of errors in the suggested price data. If all stations use their oil companies' suggested price and if there is an error in the data for the suggested price for a certain oil company on a certain day, stations with that certain brand will all deviate from the predicted price in the same manner.
} 
the gasoline stations that carry that brand over and above the possible coordinating effect of the spot market price and the average suggested price. To see whether or not this is the case, one can simply add a term to equation (1):

$$
P_{i, t}=\widetilde{\beta} \operatorname{Spot}_{t-2}+\tilde{\gamma}\left(\overline{\operatorname{Sug}}_{-i, t}-\operatorname{Spot}_{t-2}\right)+\tilde{\lambda}\left(\operatorname{Sug}_{i, t}-\overline{\operatorname{Sug}}_{-i, t}\right)+\widetilde{\eta}_{i}+\widetilde{\varepsilon}_{i, t}
$$

where $\operatorname{Sug}_{i, t}$ is the suggested price for one liter of gasoline of the oil company of the brand of station $i$ at day $t$ (excluding excise duty and VAT). The second term between brackets on the right hand side of equation (3) denotes the possible additional information in the brand specific suggested price on top of the information in the common component of the suggested prices. Its impact is measured by $\lambda$.

Again we do not estimate this equation directly because of the non-stationarity of the variables $P_{i, t}$ and $S p o t t_{t-2}$. Instead, we also rewrite equation (3) as an ECM with dynamics:

$$
\begin{aligned}
& \Delta P_{i, t}=\sum_{k=1}^{q-1} \alpha_{k} \Delta P_{i, t-k}+\sum_{k=0}^{r-1} \beta_{k} \Delta \operatorname{Spot}_{t-2-k}+\sum_{k=0}^{w-1} \gamma_{k} \Delta\left(\overline{\operatorname{Sug}}_{-i, t-k}-\operatorname{Spot}_{t-2-k}\right)+\sum_{k=0}^{v-1} \lambda_{k} \Delta\left(\operatorname{Sug}_{i, t-k}-\overline{\operatorname{Sug}}_{-i, t-k}\right)+ \\
& \phi\left[P_{i, t-1}-\beta^{*} \operatorname{Spot}_{t-3}-\gamma^{*}\left(\overline{\operatorname{Sug}}_{-i, t-1}-\operatorname{Spot}_{t-3}\right)-\lambda^{*}\left(\operatorname{Sug}_{i, t-1}-\overline{\operatorname{Sug}}_{-i, t-1}\right)-\eta_{i}^{*}\right]+\varepsilon_{i, t}
\end{aligned}
$$

If brand specific suggested prices do not have an additional explanatory effect, then the $\lambda$ 's in equation (4) should equal 0 . If the $\lambda$ 's differ significantly from zero, brand specific suggested prices have a within brand coordinating effect on retail prices.

We estimate equations (2) and (4) two times; once for our sub-sample of Euro95 prices and once for our sub-sample of Diesel prices. We use the Ordinary Least Squares (OLS) Within estimator. ${ }^{24}$ We use Driscoll-Kraay standard errors that are robust to heteroskedasticity, serial correlation and cross-sectional correlation (see

\footnotetext{
${ }^{24}$ Although this estimator is inconsistent for dynamic models if the number of observations over time is fixed (even if the number of groups goes to infinity), it is consistent if the number of observations over time also goes to infinity. Our dataset contains many stations over a relatively long period (783 days), so using the OLS Within estimator should not be a problem. A two-step estimation procedure does not qualitatively change results.
} 
Driscoll and Kraay 1998 and also Hoechle 2007). We mainly use the data we have on dodo stations as these are the stations that are completely free to determine their own prices.

\section{Results}

Table 1 below contains estimates of equation (2) and (4) for Euro95 using the data on dealer-owned gasoline stations. The first column of Table 1 corresponds to equation (2) with $\mathrm{q}=1, \mathrm{r}=1$ and $\mathrm{w}=1$. It shows that the coefficient for the immediate impact of the Euro95 spot market price on the change in the Euro95 retail price equals 0.82, so a change in the spot market price is largely reflected in the retail price. However, we also find a strong additional impact of the average suggested price, which (with a coefficient of 0.72 ) is quite substantial and highly significant. This indicates that the average suggested price contains additional information explaining retail prices over and above the fluctuations in the spot market price. The estimated value of the parameter $\phi$ is -0.31 , indicating that deviations of the retail price relative to the equilibrium price are corrected in the direction of the equilibrium price. In the longrun the changes in the spot market price are completely reflected in the retail price (the coefficient $\beta^{*}$ equals 1 ), while changes in the suggested price are largely reflected (the coefficient $\gamma^{*}$ equals 0.78 ).

The second column of Table 1 depicts estimation results for equation (2) with $q=4$, $\mathrm{r}=4$ and $\mathrm{w}=4$. Our estimates are robust to changes in the lag specification. Again, the change in the gasoline spot market price is important for explaining the change in the gasoline retail price, but so is the additional effect of the average suggested price. Also the estimation of the long-term relation provides interesting insights: the spot market price is completely, and the difference between the suggested price and the gasoline spot market price largely reflected in the gasoline retail price. The first and second columns of Table A1 in the Appendix show that estimation results of equation (2) are similar for Diesel. These results indicate that the average suggested price is important for explaining retail prices in addition to the two-day delayed spot market price. Retail prices of stations with a certain brand are explained by the additional 
information in the suggested prices of other brands. We conclude, that suggested prices have a coordinating effect across stations with different brands.

Next we estimate equation (4) to see whether there is additional information in the brand specific suggested price that retailers use for setting their price over and above the average suggested price. Our sample for estimating equation (4) contains all dealer-owned gasoline stations which have the brand of one of the five largest oil companies (since we only know the brand specific suggested price for gasoline stations with one of these five brands). The third column of Table 1 shows estimation results for equation (4) with $\mathrm{q}=1, \mathrm{r}=1, \mathrm{w}=1$ and $\mathrm{v}=1$. The fourth column shows the results with $\mathrm{q}=4, \mathrm{r}=4, \mathrm{w}=4$ and $\mathrm{v}=4$. Again the results show that the spot market price and the additional information contained in the average suggested price are important for explaining the retail price. The additional information in the brand-specific suggested price is, however, important for explaining the retail prices as well. The third and fourth column of Table A1 in Appendix A show that estimation results of equation (4) are similar for Diesel. This indicates that brand specific suggested prices have a within brand coordinating effect. We conclude that suggested prices have, next to the coordinating effect across brands, also an additional coordinating effect between stations carrying the same brand.

\section{Robustness}

We have checked the robustness of our results by estimating alternative specifications. All of these specifications underline the important qualitative aspects of the results reported so far. We now elaborate on some of the robustness checks we have performed. First, we have estimated the equations for all company-owned gasoline stations. These are the gasoline stations which are not (or possibly not completely) free to deviate from the suggested prices as set by the oil companies. The first column of Table 2 contains the estimation results of equation (2) with the $\operatorname{ECM}(1,1,1)$ specification for Euro95. The estimated coefficients are similar to those of the group of dealer-owned stations. This shows (what was to be expected) that also for company-owned gasoline stations the average suggested price is important for explaining retail prices in addition to the two-day delayed spot market price. 
Table 1. Estimation results equation (2) and equation (4) Euro95

\begin{tabular}{|c|c|c|c|c|}
\hline \multirow[b]{2}{*}{ Sample } & \multicolumn{2}{|c|}{ Equation (2) } & \multicolumn{2}{|c|}{ Equation (4) } \\
\hline & $\begin{array}{c}\operatorname{ECM}(1,1,1) \\
\mathrm{DO}\end{array}$ & $\begin{array}{c}\mathrm{ECM}(4,4,4) \\
\mathrm{DO}\end{array}$ & $\begin{array}{l}\operatorname{ECM}(1,1,1,1) \\
\text { DO \& Brand }\end{array}$ & $\begin{array}{c}\mathrm{ECM}(4,4,4,4) \\
\mathrm{DO} \& \text { Brand }\end{array}$ \\
\hline$\Delta \mathrm{P}_{\mathrm{i}, \mathrm{t}-1}$ & & $-0.33(0.01)$ & & $-0.39(0.01)$ \\
\hline$\Delta \mathrm{P}_{\mathrm{i}, \mathrm{t}-2}$ & & $-0.19(0.01)$ & & $-0.25(0.01)$ \\
\hline$\Delta \mathrm{P}_{\mathrm{i}, \mathrm{t}-3}$ & & $-0.10(0.01)$ & & $-0.13(0.01)$ \\
\hline$\Delta \mathrm{Spot}_{\mathrm{t}-2}$ & $0.82(0.01)$ & $0.84(0.02)$ & $0.88(0.01)$ & $0.92(0.01)$ \\
\hline$\Delta \mathrm{Spot}_{\mathrm{t}-3}$ & & $0.33(0.02)$ & & $0.37(0.02)$ \\
\hline$\Delta \mathrm{Spot}_{\mathrm{t}-4}$ & & $0.17(0.02)$ & & $0.25(0.01)$ \\
\hline$\Delta$ Spot $_{t-5}$ & & $0.12(0.02)$ & & $0.13(0.01)$ \\
\hline$\Delta\left(\overline{\text { Sug }}_{-i, t}-\right.$ Spot $\left._{t-2}\right)$ & $0.72(0.02)$ & $0.74(0.02)$ & $0.84(0.01)$ & $0.87(0.02)$ \\
\hline$\Delta\left(\overline{\operatorname{Sug}}_{-\mathrm{i}, \mathrm{t}-1}-\operatorname{Spot}_{\mathrm{t}-3}\right)$ & & $0.30(0.02)$ & & $0.36(0.02)$ \\
\hline$\Delta\left(\overline{\operatorname{Sug}}_{-\mathrm{i}, \mathrm{t}-2}-\mathrm{Spot}_{\mathrm{t}-3}\right)$ & & $0.17(0.02)$ & & $0.25(0.02)$ \\
\hline$\Delta\left(\overline{\text { Sug }}_{-i, t-3}-\operatorname{Spot}_{t-4}\right)$ & & $0.12(0.02)$ & & $0.13(0.02)$ \\
\hline$\Delta\left(\operatorname{Sug}_{\mathrm{i}, \mathrm{t}}-\overline{\operatorname{Sug}}_{-\mathrm{i}, \mathrm{t}}\right)$ & & & $0.67(0.02)$ & $0.69(0.02)$ \\
\hline$\Delta\left(\operatorname{Sug}_{\mathrm{i}, \mathrm{t}-1}-\overline{\mathrm{Sug}}_{-\mathrm{i}, \mathrm{t}-1}\right)$ & & & & $0.27(0.02)$ \\
\hline$\Delta\left(\operatorname{Sug}_{i,-2-2}-\overline{\operatorname{Sug}}_{-i, t-2}\right)$ & & & & $0.19(0.02)$ \\
\hline$\Delta\left(\operatorname{Sug}_{\mathrm{i},-\mathrm{-}-3}-\overline{\mathrm{Sug}}_{-\mathrm{i}, \mathrm{t}-3}\right)$ & & & & $0.10(0.01)$ \\
\hline$\Phi$ & $-0.31(0.01)$ & $-0.18(0.01)$ & $-0.29(0.01)$ & $-0.16(0.01)$ \\
\hline $\operatorname{Spot}_{\mathrm{t}-3}$ & $1.00(0.00)$ & $1.00(0.00)$ & $0.99(0.00)$ & $0.99(0.00)$ \\
\hline$\left(\overline{\operatorname{Sug}}_{-\mathrm{i},-1-1}-\operatorname{Spot}_{\mathrm{t}-3}\right)$ & $0.78(0.03)$ & $0.65(0.06)$ & $0.88(0.02)$ & $0.80(0.05)$ \\
\hline$\left(\operatorname{Sug}_{i, t-1}-\overline{\operatorname{Sug}}_{-i, t-1}\right)$ & & & $0.72(0.03)$ & $0.68(0.08)$ \\
\hline Observations & 558,909 & 293,874 & 372,450 & 219,221 \\
\hline Stations & 2,294 & 1,700 & 1,176 & 970 \\
\hline
\end{tabular}

Notes: $\mathrm{T}=783$, Driscoll-Kraay standard errors between brackets (lag length considered in the serial correlation structure determined via Newey-West procedure $\operatorname{ECM}(1,1,1)$ and $\operatorname{ECM}(1,1,1,1) 6$ lags and $\operatorname{ECM}(4,4,4)$ and $\operatorname{ECM}(4,4,4,4) 5$ lags $)$. Station specific effects are not reported. DO = dealer-owned stations, Brand = stations with the brand of one of the five largest oil companies. Note that the reported number of stations may not be exactly identical to the number of physical stations (some gasoline stations change their name during the sample period and we do not merge the series of these stations). 
Second, we have estimated the equations for sub-samples of our population of dealerowned gasoline stations to take into account possible heterogeneity of stations. To this end, we grouped gasoline stations based on location (highway or non-highway) and brand. Table 2 contains the estimation results of equation (2) with the $\operatorname{ECM}(1,1,1)$ specification with Euro95 data for each of these respective cases. The second and third column show estimation results for respectively dealer-owned gasoline stations that are located along a highway and dealer-owned stations that are not located at a highway. In both cases, we confirm the general conclusion that the average suggested price is important for explaining retail prices in addition to the spot market price. The fourth and fifth column show estimation results for respectively dealer-owned stations with the brand of one of the five largest oil companies and dealer-owned stations with another brand. These columns confirm the same conclusion for both cases. This indicates that the suggested prices of the five largest oil companies not only have a coordinating effect on retail prices of stations that carry the brand of one of the five largest oil companies, but importantly they also have a coordinating effect on the retail prices of other gasoline stations. In the lower part of Table 2 the dealer-owned gasoline stations with the brand of one of the five largest oil companies are grouped by brand. It shows that for some brands, the coefficient that measures the impact of the average suggested price on retail prices is more significant than for stations with other brands. ${ }^{25}$

We have also estimated alternative versions of equation (2) and (4), replacing the average suggested price by the Shell suggested price (as Shell is considered by some to be the price leader in the Dutch gasoline retail market). These estimations provide similar results as the equations using the average suggested price. The information in the brand specific suggested prices that is additional to the Shell suggested price is important for explaining retail prices of gasoline stations with the brand of one of the four other oil companies.

\footnotetext{
${ }^{25}$ We performed the same robustness checks as reported in Table 2 for equation (4) and for our subsample of Diesel observations. The results are not reported here as their qualitative conclusions are similar to the conclusions of the checks reported in Table 2.
} 
Table 2. Robustness of results equation (2) Euro95

\begin{tabular}{|c|c|c|c|c|c|}
\hline \multirow[b]{3}{*}{ Sample } & \multicolumn{5}{|c|}{ Equation (2) } \\
\hline & \multicolumn{5}{|c|}{$\operatorname{ECM}(1,1,1)$} \\
\hline & $\mathrm{CO}$ & DO \& Highway & DO \& Non-highway & DO \& Brand & DO \& No brand \\
\hline$\Delta \mathrm{Spot}_{\mathrm{t}-2}$ & $0.82(0.01)$ & $0.83(0.01)$ & $0.82(0.02)$ & $0.79(0.02)$ & $0.88(0.02)$ \\
\hline$\Delta\left(\overline{\text { Sug }}_{-i, t}-\right.$ Spot $\left._{t-2}\right)$ & $0.73(0.02)$ & $0.73(0.02)$ & $0.72(0.02)$ & $0.69(0.02)$ & $0.81(0.02)$ \\
\hline$\Phi$ & $-0.26(0.01)$ & $-0.37(0.02)$ & $-0.30(0.01)$ & $-0.31(0.01)$ & $-0.30(0.01)$ \\
\hline $\operatorname{Spot}_{\mathrm{t}-3}$ & $1.00(0.00)$ & $1.00(0.00)$ & $1.00(0.00)$ & $1.00(0.00)$ & $0.99(0.00)$ \\
\hline$\left(\overline{\operatorname{Sug}}_{-\mathrm{i}, \mathrm{t}-1}-\operatorname{Spot}_{\mathrm{t}-3}\right)$ & $0.77(0.03)$ & $0.85(0.03)$ & $0.77(0.03)$ & $0.76(0.03)$ & $0.81(0.03)$ \\
\hline Observations & 705,730 & 22,824 & 536,085 & 372,450 & 186,459 \\
\hline Stations & 1,590 & 61 & 2,233 & 1,176 & 1,118 \\
\hline
\end{tabular}

\begin{tabular}{|c|c|c|c|c|c|}
\hline \multirow[b]{3}{*}{ Sample } & \multicolumn{5}{|c|}{ Equation (2) } \\
\hline & \multicolumn{5}{|c|}{$\operatorname{ECM}(1,1,1)$} \\
\hline & DO \& Brand A & DO \& Brand B & DO \& Brand C & DO \& Brand D & DO \& Brand E \\
\hline$\Delta \mathrm{Spot}_{\mathrm{t}-2}$ & $0.83(0.03)$ & $0.83(0.04)$ & $0.79(0.03)$ & $0.71(0.03)$ & $0.82(0.03)$ \\
\hline$\Delta\left(\overline{\text { Sug }}_{-i, \mathrm{t}}-\right.$ Spot $\left._{\mathrm{t}-2}\right)$ & $0.75(0.04)$ & $0.69(0.05)$ & $0.58(0.04)$ & $0.67(0.03)$ & $0.80(0.03)$ \\
\hline$\Phi$ & $-0.33(0.01)$ & $-0.31(0.01)$ & $-0.30(0.01)$ & $-0.28(0.01)$ & $-0.36(0.01)$ \\
\hline $\operatorname{Spot}_{t-3}$ & $0.99(0.00)$ & $0.99(0.00)$ & $1.00(0.00)$ & $1.00(0.01)$ & $0.99(0.00)$ \\
\hline$\left(\overline{\operatorname{Sug}}_{-\mathrm{i}, \mathrm{t}-1}-\operatorname{Spot}_{\mathrm{t}-3}\right)$ & $0.96(0.05)$ & $0.56(0.06)$ & $0.65(0.05)$ & $1.09(0.07)$ & $0.85(0.05)$ \\
\hline Observations & 54,913 & 128,014 & 67,141 & 64,096 & 58,286 \\
\hline Stations & 290 & 282 & 190 & 270 & 144 \\
\hline
\end{tabular}

Notes: $\mathrm{T}=783$, Driscoll-Kraay standard errors between brackets (lag length considered in the serial correlation structure determined via Newey-West procedure (6 lags). Station specific effects are not reported. $\mathrm{CO}=$ company owned stations, $\mathrm{DO}=$ dealer owned stations, Brand $=$ stations with the brand of one of the five largest oil companies. Note that the reported number of stations may not be exactly identical to the number of physical stations (some gasoline stations change their name during the sample period and we do not merge the series of these stations). 


\section{Coordinating role or influencing the cost of retailers?}

In the previous section we have shown that suggested prices have a coordinating effect in the sense that they contain information that helps to explain retail prices in addition to the international spot market price for gasoline. This is, however, not necessarily a sign that gasoline stations coordinate their pricing decisions using the suggested price as a means. An alternative hypothesis is that there is a third variable that is influenced by the suggested price and that is used by retail companies to determine which price to set. If there is such a third variable, the most natural way to think about this is in terms of costs. An alternative hypothesis then is that retailers buy gasoline at a cost price that depends on the suggested price. If this is the case, then retail prices do depend on suggested prices through their impact on costs (not as an independent factor coordinating retail prices). In this section we will disentangle these two hypotheses. The method for doing so cannot rely on cost data, as this data is not available.

What we do know is that stations do not buy gasoline every day. According to Beta (the organization for independent gasoline retailers), many stations are supplied with new stock three times a week (Van Gelder 2008). Naturally, there are important differences between stations. ${ }^{26}$ This means that each day on average $43 \%(3 / 7)$ of the gasoline stations get new stock. ${ }^{27}$ We also know the dates at which the suggested prices change and also that these dates are independent of the delivery moments of new gasoline to stations. As a consequence, if the cost of a liter of gasoline depends on the suggested price and if gasoline stations simply adjust their retail price to the cost level, we expect that only $43 \%$ of all gasoline stations will change their price when the suggested price changes (and the suggested price is not equal to the suggested price on the previous day that the gasoline stations bought new stock). ${ }^{28} \mathrm{We}$

\footnotetext{
${ }^{26}$ It is clear that the delivery pattern of a station depends on the capacity to stock gasoline and on turnover.

${ }^{27}$ Other sources mention that on average gasoline stations are supplied 1.5 times per week, so that 3 times a week really seems to be an upper bound. Moreover, our conclusions do not change if we assume that gasoline stations only get new stock on working days.

${ }^{28}$ One may argue that we should look at a notion of opportunity cost, and not accounting cost. However, once the gasoline is brought to the retailers' station and stocked, opportunities alternative to selling the gasoline to clients are very limited so that using the notion of opportunity cost does not make much sense in this context. Alternatively, if cost is related to suggested price, then the suggestion of the oil companies to retailers could be that if they had to buy gasoline on that day, they would have to pay a price related to the suggested price. Again, however, if this does not reflect opportunity cost,
} 
can therefore check how many gasoline stations change their retail prices on days that the suggested price changes to discriminate between the two alternative hypotheses. The cost hypothesis says that on days that the suggested price changes to a level that is unequal to the level at any recent day, at most $43 \%$ of the stations should change their price. The coordinated effect hypothesis says that this percentage is (much) higher: it does not say that it should be $100 \%$ as this would be implied only if the suggested prices fully coordinate retail prices (which we know is not the case) and there are no menu costs or other costs of price adjustments.

For this purpose, we select out of our dataset all days at which there is a change in at least one suggested price and where the suggested price of this specific brand is not equal to this suggested price on any of the days in the week before. If the cost hypothesis is true, the cost of gasoline at these days differs for all stations that carry this brand from the cost at the previous time these stations bought gasoline. For Euro95 there are 290 days that satisfy this restriction. For each of these days, we take the gasoline stations for which the suggested price changes and calculate the percentage of stations that change their price with respect to the previous day. We restrict attention to dealer-owned stations that carry the brand of one of the five largest oil companies.

Figure 5 shows the percentage of stations that change their price on a certain day (for Euro95, results for Diesel are similar). For example, on 213 out of 290 days more than $60 \%$ of the stations change their price if the suggested price changes. Figure 5 shows that in the majority of days substantially more than $43 \%$ of the stations change their price. In only 18 out of the 290 days less than $43 \%$ of the stations change their price. We also restrict attention to those days for which the change in the suggested price is more than 1 cent to allow for retailers not adjusting their price due to small menu costs. In this case only 99 days satisfy the restriction and the figure shows even more sharply that the cost hypothesis is unlikely to be true.

and if retailers do not buy on a particular day, then there is no clear rationale why to follow that day's suggested price. 
Figure 5. Percentage of stations that change their retail price on days that the suggested price changes (and the suggested price is different than in the week before)

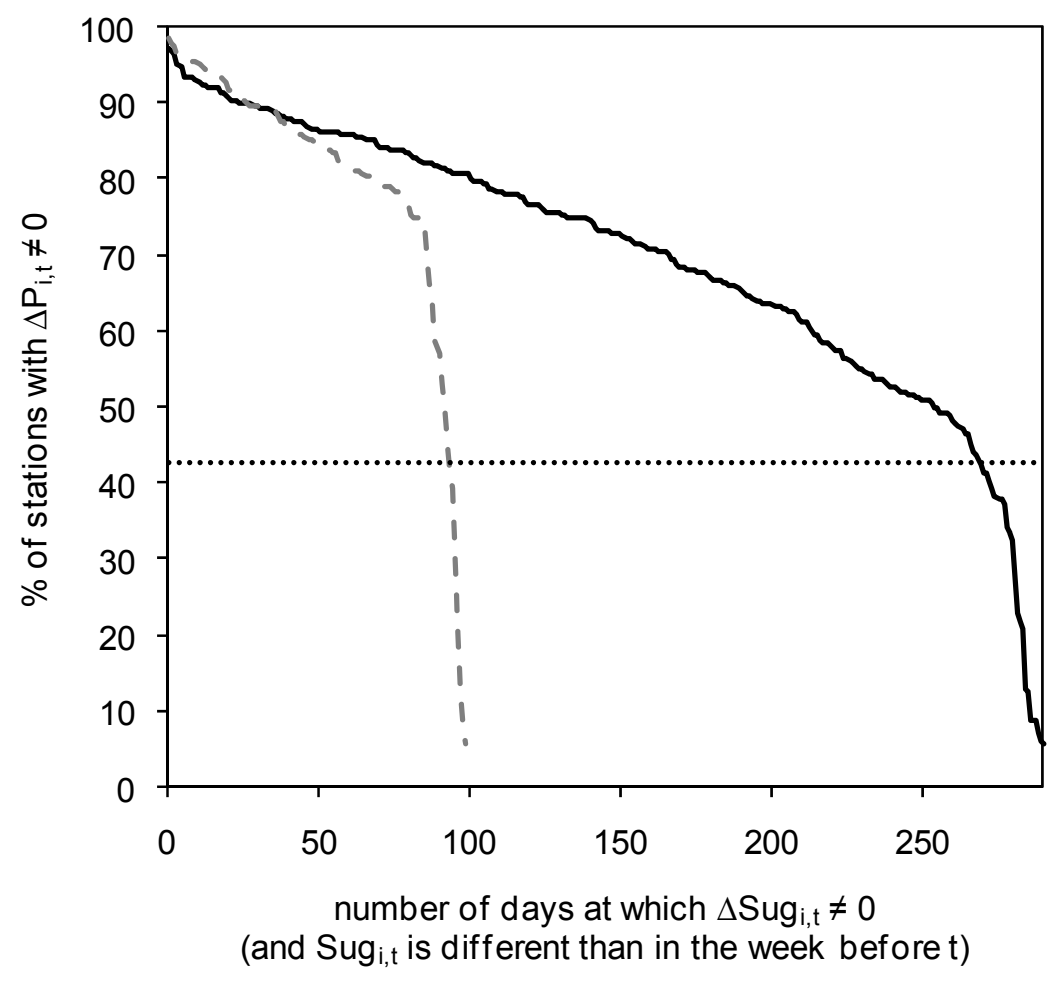

$-\Delta S U G i, t \neq 0 \quad--|\Delta S U G i, t|>0.01$

We performed a sign test to the hypothesis that the median is equal to $43 \%$ against the alternative hypothesis that it is larger than $43 \%$. For both Euro95 and Diesel the sign test rejects the cost hypothesis at a $1 \%$ significance level. This indicates that the cost hypothesis is unlikely and thus that in all likelihood there is a direct coordinating effect of suggested prices on retail prices independent of their possible effect on cost. In Appendix B we strengthen this conclusion by showing that most gasoline stations follow exactly the change in the suggested price on most days.

\section{Conclusion}

This paper examines the impact of suggested prices on gasoline retail prices using a large panel dataset containing almost all gasoline stations in the Netherlands. Our results show that changes in suggested prices do more than just summarizing changes 
in the spot market price. Retailers use the additional information contained in the suggested prices for setting their own prices. This is not only true for the average suggested price, but also for the brand specific suggested price. We therefore conclude that the regime where the five largest oil companies set their own suggested price has a coordinating effect across brands and within brands. We also show that it is very unlikely that this coordinating effect is caused by the possible indirect effect of changes in suggested prices on changes in the underlying retailers' costs.

It is important to stress that this coordinating effect does not imply that most retailers simply charge the suggested price. In fact, many retailers give a discount on the suggested price. What we show is that the discount vis-à-vis the suggested price is almost constant so that almost all retailers follow changes in suggested prices.

The coordinating effect on retail prices can be easily explained in terms of a theory of tacit collusion. Under tacit collusion, it is important to have a focal point on which to coordinate price decisions. Suggested prices can act as such a focal point. It is also clear that this coordinating effect cannot arise in a perfectly competitive industry. In such an industry it can be that different retailers set different prices as their costs differ. However, by taking first differences on a daily basis, we filter out cost differences between retailers that are constant over time (like costs associated with for example location and loyalty programs). The only possible daily fluctuations in cost levels are related to changes in the (common) international spot market price and in a perfectly competitive industry, retailers change their prices in reaction to these changes. Additional information in suggested prices does not have a role to play.

We do not exclude that there may exist theories explaining the data patterns we discovered that do not rely on tacit collusion. However, we have not been able to come up with such theories. This will be an interesting area for further research. Even though the coordinating effect we found does not yield full coordination of retail prices, we think it is important enough to deserve further scrutiny from competition authorities and other researchers. 


\section{References}

Bettendorf, Leon, Stéphanie A. van der Geest and Gerard H. Kuper. (2008) “Do Daily Retail Gasoline Prices Adjust Asymmetrically?" Journal of Applied Statistics, forthcoming.

Bettendorf, Leon, Stéphanie A. van der Geest and Marco Varkevisser. (2003) "Price Asymmetry in the Dutch Retail Gasoline Market." Energy Economics, 25(6), pp. 669-689.

Borenstein, Severin. (2004) "Rapid Price Communication and Coordination: The Airline Tariff Publishing Case (1994)." In The Antitrust Revolution: Economics, Competition, and Policy, edited by John E. Kwoka, Jr., and Lawrence J. White, $4^{\text {th }}$ ed., pp. 233-251. New York: Oxford UP.

Borenstein, Severin, A. Colin Cameron and Richard Gilbert. (1997) "Do Gasoline Prices Respond Asymmetrically to Crude Oil Price Changes?" Quarterly Journal of Economics, 112(1), pp. 305-339.

BOVAG. (2006) Tankstations in cijfers 2006-2007. Bunnik.

Choi, In. (2001) “Unit Root Tests for Panel Data.” Journal of International Money and Finance, 20(2), pp. 249-272.

Driscoll, John C. and Aart C. Kraay. (1998) "Consistent Covariance Matrix Estimation with Spatially Dependent Panel Data." Review of Economics and Statistics, 80(4), pp. 549-560.

Foros, Øystein and Frode Steen. (2008) "Gasoline Prices Jump up on Mondays: An Outcome of Aggressive Competition?” CEPR Discussion Paper 6783.

Hay, George A.. (1999) "Facilitating Practices: The Ethyl Case (1984)." In The Antitrust Revolution: Economics, Competition, and Policy, edited by John E. Kwoka, Jr., and Lawrence J. White, $3^{\text {rd }}$ ed., pp. 182-201. New York: Oxford UP.

Hoechle, Daniel. (2007) "Robust Standard Errors for Panel Regressions with Cross-Sectional Dependence.” Stata Journal, 7(3), pp. 281-312.

Kao, Chihwa. (1999) "Spurious Regression and Residual-Based Tests for Cointegration in Panel Data." Journal of Econometrics, 90(1), pp. 1-44.

Knittel, Christopher R. and Victor Stango. (2003) "Price Ceilings As Focal Points for Tacit Collusion: Evidence from Credit Cards." American Economic Review, 93(5), pp. 1703-1729. 
Maddala, G. S. and Shaowen Wu. (1999) “A Comparative Study of Unit Root Tests with Panel Data and a New Simple Test." Oxford Bulletin of Economics and Statistics, 61(S1), pp. 631-652.

OECD. (2001) "Price Transparency." Roundtables on Competition Policy DAFFE/CLP(2001)22.

Shell. (2001) "Het is echt heel transparant. Hoe ontstaan de adviesprijzen voor benzine?" Shell Venster, July/August, pp. 16-18.

Van Gelder, Harry. (2008) "Bumpersticker tegen hoge benzineprijzen." De Telegraaf, 116(37596), p. T3. 


\section{Appendix A Figures and tables}

Figure A1. Shell suggested price, retail price of a representative Shell station and spot market price for one liter Diesel

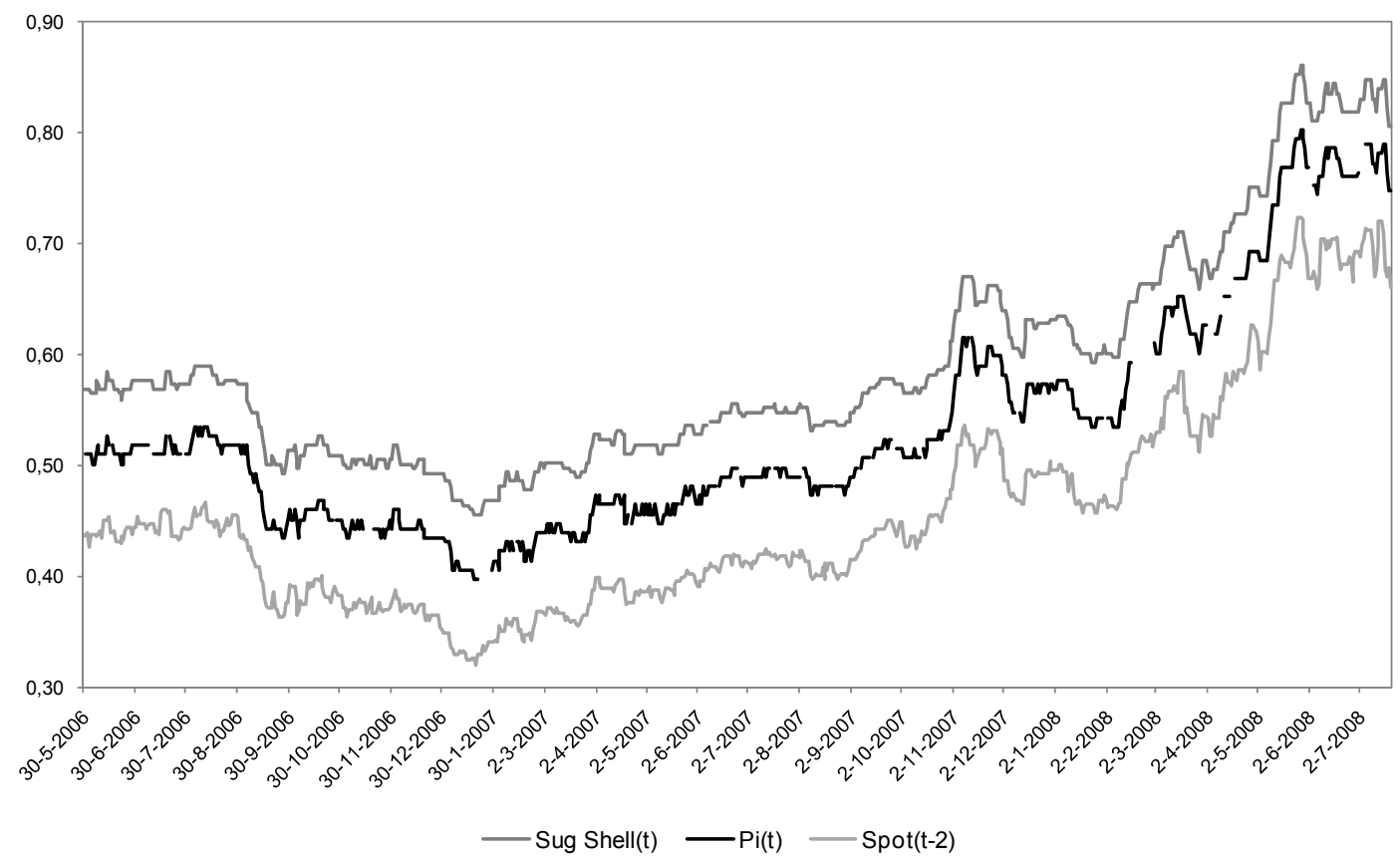

Notes: $\mathrm{T}=783$, price in euro per liter (excluding excise duty and VAT) 
Figure A2. Suggested price - Spot market price for all five brands (Euro95)
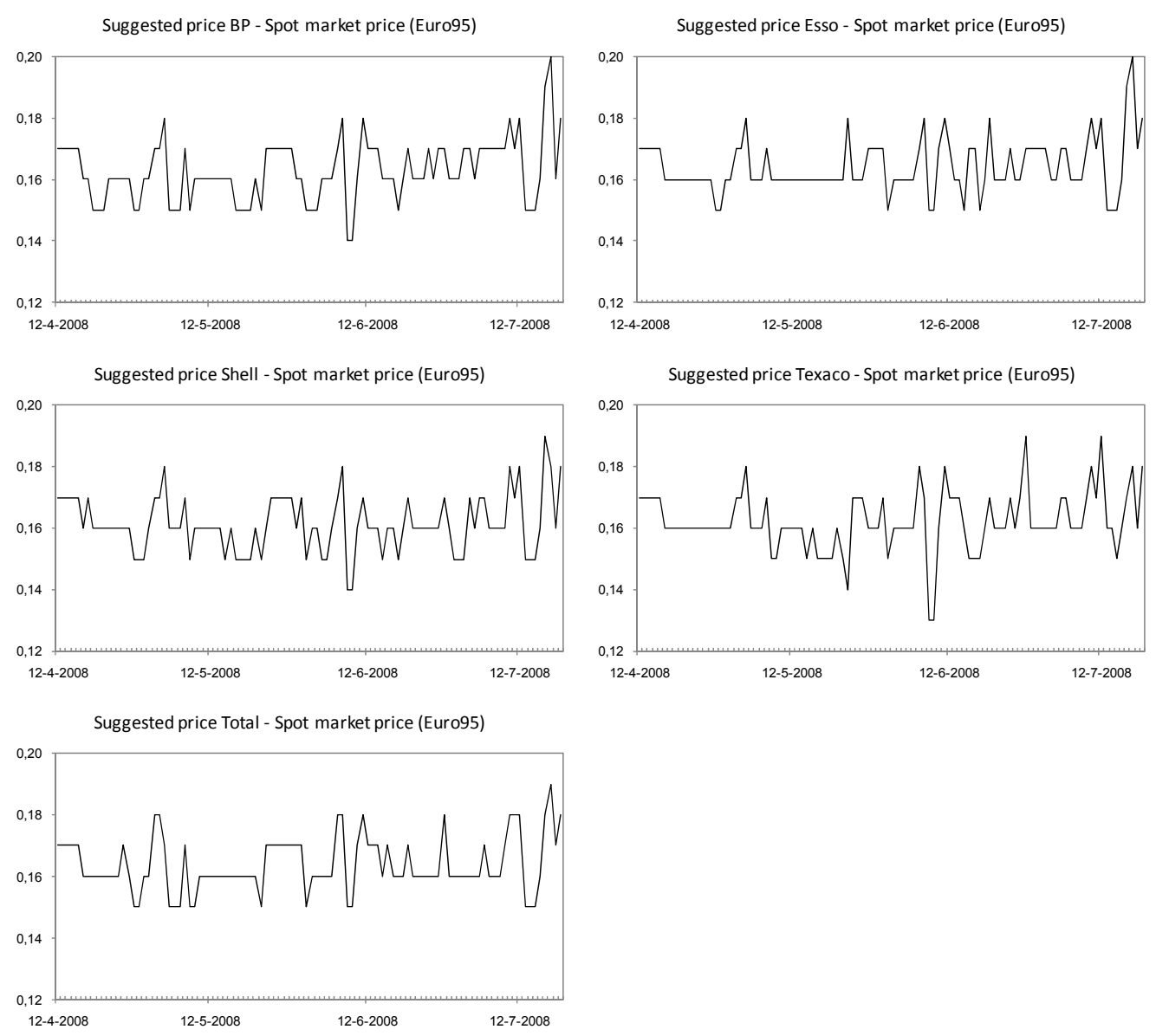

Notes: $\mathrm{T}=100$, difference in euro per liter (excluding excise duty and VAT) 
Table A1. Estimation results equation (2) and equation (4) Diesel

\begin{tabular}{|c|c|c|c|c|}
\hline \multirow[b]{2}{*}{ Sample } & \multicolumn{2}{|c|}{ Equation (2) } & \multicolumn{2}{|c|}{ Equation (4) } \\
\hline & $\begin{array}{c}\mathrm{ECM}(1,1,1) \\
\mathrm{DO}\end{array}$ & $\begin{array}{c}\mathrm{ECM}(4,4,4) \\
\mathrm{DO}\end{array}$ & $\begin{array}{l}\operatorname{ECM}(1,1,1,1) \\
\text { DO \& Brand }\end{array}$ & $\begin{array}{l}\text { ECM }(4,4,4,4) \\
\text { DO \& Brand }\end{array}$ \\
\hline$\Delta \mathrm{P}_{\mathrm{i}, \mathrm{t}-1}$ & & $-0.31(0.01)$ & & $-0.37(0.01)$ \\
\hline$\Delta \mathrm{P}_{\mathrm{i}, \mathrm{t}-2}$ & & $-0.18(0.01)$ & & $-0.22(0.01)$ \\
\hline$\Delta \mathrm{P}_{\mathrm{i}, \mathrm{t}-3}$ & & $-0.11(0.01)$ & & $-0.11(0.01)$ \\
\hline$\Delta \mathrm{Spot}_{\mathrm{t}-2}$ & $0.84(0.01)$ & $0.87(0.02)$ & $0.89(0.01)$ & $0.93(0.01)$ \\
\hline$\Delta$ Spot $_{-3}$ & & $0.30(0.02)$ & & $0.34(0.01)$ \\
\hline$\Delta$ Spot $_{-4}$ & & $0.14(0.02)$ & & $0.20(0.01)$ \\
\hline$\Delta$ Spot $_{t-5}$ & & $0.11(0.01)$ & & $0.11(0.01)$ \\
\hline$\Delta\left(\overline{\text { Sugg }}_{-i, t}-\right.$ Spot $\left._{t-2}\right)$ & $0.76(0.02)$ & $0.79(0.02)$ & $0.86(0.01)$ & $0.89(0.01)$ \\
\hline$\Delta\left(\overline{\operatorname{Sug}}_{-\mathrm{i}, \mathrm{t}-1}-\mathrm{Spot}_{\mathrm{t}-3}\right)$ & & $0.27(0.02)$ & & $0.33(0.02)$ \\
\hline$\Delta\left(\overline{\mathrm{Sug}}_{-\mathrm{i}, \mathrm{t}-2}-\mathrm{Spot}_{\mathrm{t}-3}\right)$ & & $0.13(0.02)$ & & $0.20(0.02)$ \\
\hline$\Delta\left(\overline{\text { Sug }}_{-\mathrm{i}, \mathrm{t}-3}-\mathrm{Spot}_{\mathrm{t}-4}\right)$ & & $0.09(0.01)$ & & $0.11(0.01)$ \\
\hline$\Delta\left(\right.$ Sug $\left._{i, t}-\overline{\text { Sug }}_{-i, t}\right)$ & & & $0.63(0.02)$ & $0.66(0.02)$ \\
\hline$\Delta\left(\operatorname{Sug}_{\mathrm{i}, \mathrm{t}-1}-\overline{\mathrm{Sug}}_{-\mathrm{i}, \mathrm{t}-1}\right)$ & & & & $0.24(0.02)$ \\
\hline$\Delta\left(\right.$ Sug $\left._{\mathrm{i}, \mathrm{t}-2}-\overline{\mathrm{Sug}}_{-\mathrm{i}, \mathrm{t}-2}\right)$ & & & & $0.16(0.01)$ \\
\hline$\Delta\left(\right.$ Sug $\left._{\mathrm{i}, \mathrm{t}-3}-\overline{\text { Sug }}_{-\mathrm{i}, \mathrm{t}-3}\right)$ & & & & $0.07(0.01)$ \\
\hline$\Phi$ & $-0.30(0.01)$ & $-0.19(0.01)$ & $-0.29(0.01)$ & $-0.16(0.01)$ \\
\hline Spot $_{t-3}$ & $1.00(0.00)$ & $1.00(0.00)$ & $1.00(0.00)$ & $1.00(0.00)$ \\
\hline$\left(\overline{\operatorname{Sug}}_{-\mathrm{t},-1-1}-\right.$ Spot $\left._{\mathrm{t}-3}\right)$ & $0.80(0.03)$ & $0.69(0.07)$ & $0.92(0.02)$ & $0.80(0.06)$ \\
\hline$\left(\operatorname{Sug}_{i, t-1}-\overline{\operatorname{Sug}}_{-i, t-1}\right)$ & & & $0.68(0.03)$ & $0.67(0.07)$ \\
\hline Observations & 760,151 & 440,488 & 483,469 & 310,726 \\
\hline Stations & 2,351 & 2,040 & 1,209 & 1,108 \\
\hline
\end{tabular}




\section{Appendix B Most gasoline stations follow the suggested price on most days}

Figure 2 suggests already that the four selected gasoline stations follow the suggested price almost every day, a fact that is difficult to explain by the hypothesis that the suggested prices influence the retail prices only through their impact on the cost. To do the analysis more rigorously, we first pool all our retail price data across time and stations. $^{29}$ Table B1 shows how often a retail price changes, given that the relevant suggested price (the suggested price of the oil company with the brand of the gasoline station) changes. It shows that if the suggested price changes, the retail price is also changed in $73 \%$ of all cases. Moreover, if the suggested price does not change, the retail price also does not change in $77 \%$ of all cases. We split the upper left cell of Table B1 for the direction of the suggested price change. If the suggested price increases, then $97 \%$ of all changing retail prices increase as well. Furthermore, if a suggested price decreases, than $96 \%$ of all changing retail prices decrease.

Table B1. Frequencies of retail price changes conditional on suggested price changes

\begin{tabular}{|c|c|c|}
\hline & if $\Delta$ Sug $_{i, \mathrm{t}} \neq 0$ & if $\Delta$ Sug $_{\mathrm{i}, \mathrm{t}}=0$ \\
\hline \hline$\Delta \mathrm{P}_{\mathrm{i}, \mathrm{t}} \neq 0$ & $73 \%$ & $23 \%$ \\
$\Delta \mathrm{P}_{\mathrm{i}, \mathrm{t}}=0$ & $27 \%$ & $77 \%$ \\
\hline & $100 \%$ & $100 \%$ \\
\hline
\end{tabular}

Next we analyze the size of the differences. The first column of Table B2 shows that in $72 \%$ of all observations, the size of the change in the retail price equals the change in the suggested price. If the suggested price changes, $57 \%$ of all changes in the retail price are equal to the change in the suggested price. The fourth column of Table B3 shows that if both the suggested price and the retail price change, than in $78 \%$ of all cases the change in the retail price equals the change in the suggested price.

Table B2. Frequencies of a similar change in the retail price and suggested price

\begin{tabular}{|l|c|c|c|c|}
\hline & & if $\Delta$ Sug $_{\mathrm{i}, \mathrm{t}} \neq 0$ & If $\Delta$ Sug $_{\mathrm{i}, \mathrm{t}}=0$ & if $\Delta$ Sug $_{\mathrm{i}, \mathrm{t}} \neq 0$ and $\Delta \mathrm{P}_{\mathrm{i}, \mathrm{t}} \neq 0$ \\
\hline \hline$\Delta \mathrm{P}_{\mathrm{i}, \mathrm{t}}=\Delta$ Sug $_{\mathrm{i}, \mathrm{t}}$ & $72 \%$ & $57 \%$ & $77 \%$ & $78 \%$ \\
$\Delta \mathrm{P}_{\mathrm{i}, \mathrm{t}} \neq \Delta$ Sug $_{\mathrm{i}, \mathrm{t}}$ & $28 \%$ & $43 \%$ & $23 \%$ & $22 \%$ \\
\hline & $100 \%$ & $100 \%$ & $100 \%$ & $100 \%$ \\
\hline
\end{tabular}

\footnotetext{
${ }^{29}$ Calculations in this Appendix are based on Euro95 observations of dealer-owned stations with the brand of one of the five largest oil companies. We only report results for Euro95 since results for Diesel are similar.
} 